\title{
A REVIEW OF GENERIC SKILLS FOR EMPLOYABILITY OF AUTISTIC INDIVIDUALS
}

\author{
Nurul Amalin Mohamad Razali*, Hanifah Jambari, Nur Hazirah Noh@Seth, Nornazira Suhairom, \\ Sharifah Osman, Jamilah Ahmad, Mohd Rashidi Pairan \\ School of Education, Faculty of Social Sciences and Humanities, Universiti Teknologi Malaysia \\ (UTM), 81310 Skudai, Johor, Malaysia \\ *amalinnurul@ymail.com
}

\begin{abstract}
Autism is a spectral disorder where symptoms can be present in various combinations, from mild to severe. Autism can make it difficult for a child to communicate and interact with others. However, most individuals with autism are unemployed yet they need jobs to secure their future. Therefore, the purpose of this article is to review the evidence regarding generic skills for individuals with autism who possess skills in social skills, independent living skills, and cognitive skills in becoming employees. Information was searched from journals via the Universiti Teknologi Malaysia's (UTM) library website. The findings revealed social skills, independent living skills, and cognitive skills are related to generic skills for employability of autistic children. Hence, in-depth studies on skills of independent living and cognitive need to be expanded as skills are very important to prove they are capable of working.
\end{abstract}

Keywords: Autism, Generic Skills

\section{INTRODUCTION}

Autism is, spectral disorders in which means the child's symptoms can be present in various combinations, from mild to severe. Autism can make it difficult for a child to communicate and interact with others. It can also cause children to repeat activities and movements, become frustrated with changes in daily routine, and have an overwhelming response to certain situations (IOWA, 2010). Therefore, not all types or occupations are in line with individuals with this autism. But most individuals with autism are unemployed and they want jobs to secure their future. This is because most of them have their own talents or skills in a job. Many employers are difficult to give individuals with autism this job opportunity as most employers do not want to take risks and also do not have a deep knowledge of this autism. While people that have autism are more skilled job compared to normal individuals. Therefore, this article is to know the appropriate generic skills for autism individuals so they can work and earn their income in the future. Studies that have been made in the past will be grouped into reference materials for this study.

Every individual needs a job, regardless of whether the individual has a normal or abnormal life. Similarly, individuals with autism spectrum disorder (ASD). Many are aware that individuals with ASD are weak or lacking such as in communication, social skills as well as some who are weak in thinking ability. But, this does not prevent them from building their own future. Therefore, there are some generic skills that are described as well as appropriate to these autism individuals for them to work like social skills. As stated that social mentality is played an important part for adult social as well as vocational admissions with ASD. Social Distress Current research shows that social deficits are the main cause that is an important obstacles to successful work for ASD's people (Chen et al., 2015; Hendricks, 2010). So, there are some steps that may be the opportunity to participate in various vocational programs such as enhancement of vocational programs with life skills, vocational counseling and youth instruction with ASD, chance to continuous job skills development together with INSET and counseling, funding to workers and compatible policies against this entry (Syriopoulou et al., 2016).

The aim of education especially peoples that have ASD is to give chance to earn skills improve selfreliance and social responsibility (Hendricks, 2011). Individuals with autism are difficult to be 
independent and they only expect their families to care for their parents. However, parents need to realize that they are not always with their children who have this autism. So, parents need to play an important role to train their children with autism to be more self-reliant with giving their children confidence to work and to have their own career. This is because with proper education, training, and continuous support, some ASD's people can potentially evolving in job settings (Walsh et al., 2014). For example, seeking a vocational programs is the self-determination for workers, and contributes to a competitive and lasting job while reduce dependent on the work of supervisor or other employees (Lancioni \& Reilly, 2001). This is because there are some benefits of using technology, such as supporting video-based, to promote independence in job arrangements (Van, 2012). Therefore, the intervention using technology allows this independence to be real much easier (Seaman \& CannellaMalone, 2016).

Cognition is sometimes defined as a mental process in which to find out something includes aspects such as consciousness, perception, thought, and judgment. In short, cognition means thinking. Some people in the autism spectrum have excellent cognitive skills. Cognition is sometimes defined as a mental process in which to find out something includes aspects such as consciousness, perception, thought, and judgment. In short, cognition means thinking. Some people in the autism spectrum have excellent cognitive skills. Hence, employers who want autism workers must have knowledge of cognition skills for these individuals. But unfortunately, the previous literature review has showed the lack of study on vocational skills among them with autism, despite positive findings on the impact of involvement in welfare-related work activities, quality of life, and cognitive functioning for these individuals (Walsh et al., 2014). Therefore, the strong evidence for the positive advantage of vocational intervention on occupation, the main symptom for autism individuals, and cognitive development inadequate at this point means we cannot estimate the possible effects without further research (Taylor, 2012)

\section{Objectives}

This paper is systematically reviews evidence regarding generic skills for people that have autism who possess skills in social skills, independent living skills, and cognitive skills for an employee

\section{METHODOLOGY}

Review of relevant literature was used to collect data for this article. Subscribed journals were accessed via Universiti Teknologi Malaysia (UTM) library website at www.utm.my/spz. To thoroughly identify the study, the main term has been searched in a published and unpublished repository literature. The database consists of Google scholar, Google, reviewed the main ASD Association website. Therefore, all identified articles are reviewed using a three-stage recruitment and synthesis process comprising which is:

a. Initialization of screening such as title and abstract review based on keyword based database

b. Strict checks for inclusion or exclusion criteria

c. Data extraction and article review.

The review process consists of comprehensive research assistant training for accordant data exaction. Synthesis findings are generated through focus on conceptual content that include the results and themes within across studies. So that, the conceptual schemes have been developed for comparative analysis of rhythms where interventions and results are reviewed and analyzed individually, and then categorized into the same theme.

\section{RESULTS AND DISCUSSION}

Table 1. The review on generic skills for autism is feasible for working 
The Turkish Online Journal of Design, Art and Communication - TOJDAC

ISSN: 2146-5193, September 2018 Special Edition, p.840-846

\begin{tabular}{|c|c|c|c|}
\hline Title/Authors & Objectives & Findings/Results & Recommendation/Suggestions \\
\hline $\begin{array}{l}\text { Review on } \\
\text { vocational } \\
\text { training and } \\
\text { employment of } \\
\text { individuals } \\
\text { with autism } \\
\text { spectrum } \\
\text { disorder } \\
\text { Syriopoulou et } \\
\text { al. (2016) }\end{array}$ & $\begin{array}{l}\text { To review the } \\
\text { programs of } \\
\text { vocational training } \\
\text { as well as education } \\
\text { transition and } \\
\text { providing critical } \\
\text { assessments for } \\
\text { adult's A S D } \\
\text { employment }\end{array}$ & 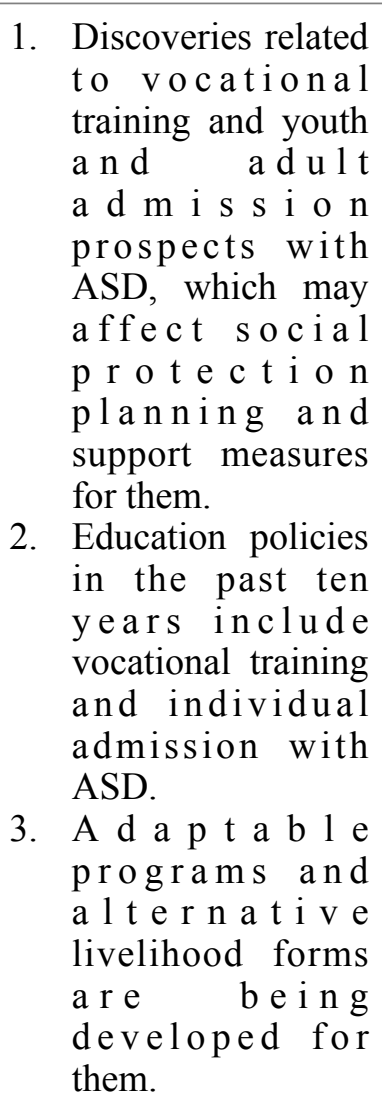 & $\begin{array}{l}\text { Social mentality plays an } \\
\text { important role in adult social } \\
\text { and vocational admissions. }\end{array}$ \\
\hline
\end{tabular}




\begin{tabular}{|c|c|c|c|}
\hline 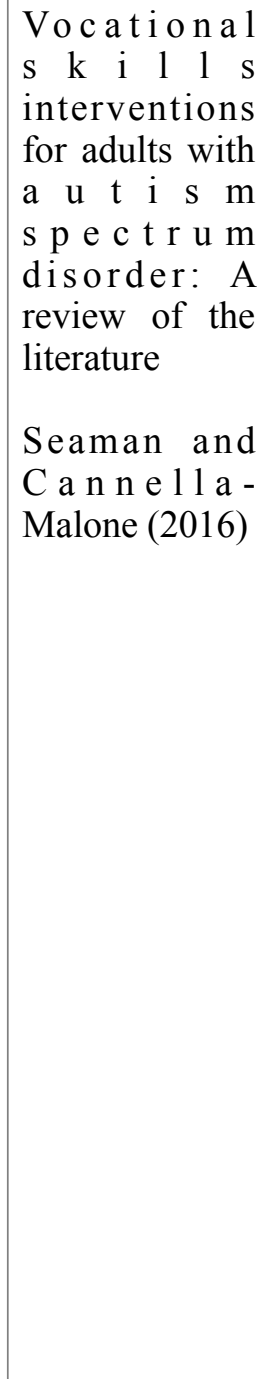 & $\begin{array}{l}\text { This study focuses } \\
\text { on the intervention } \\
\text { of voc ational } \\
\text { training focused } \\
\text { especially for ASD } \\
\text { people. }\end{array}$ & 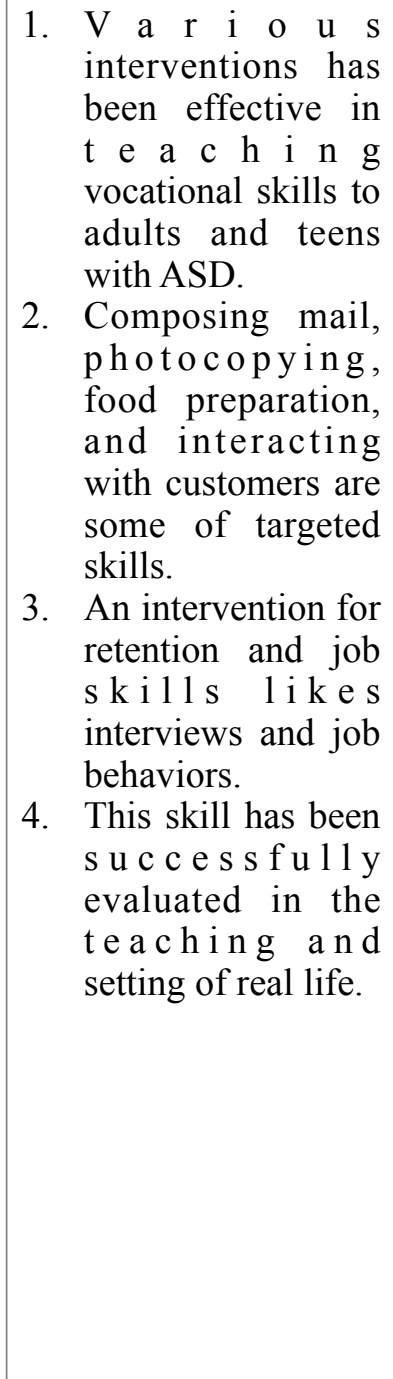 & 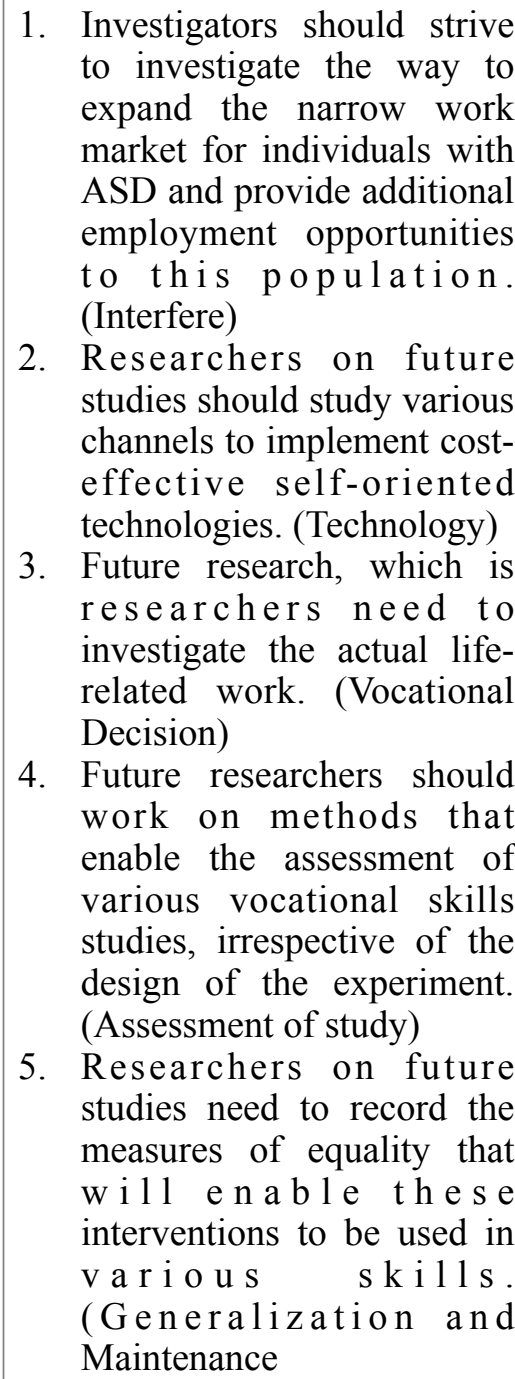 \\
\hline $\begin{array}{l}\text { Trends in } \\
\text { employment } \\
\text { for individuals } \\
\text { with autism } \\
\text { s p e tr u m } \\
\text { disorder: A } \\
\text { review of the } \\
\text { res e a c h } \\
\text { literature } \\
\text { Chen et al. } \\
(2015)\end{array}$ & $\begin{array}{l}\text { The purpose of this } \\
\text { study is to provide } \\
\text { an overview of } \\
\text { oc c u a tion a } 1 \\
\text { rese a c h in } \\
\text { individuals with } \\
\text { ASD and improve } \\
\text { our understanding } \\
\text { of the factors } \\
\text { a f f e c ting the } \\
\text { occupation of this } \\
\text { population. }\end{array}$ & $\begin{array}{l}\text { 1. Job results are } \\
\text { disclosed from } \\
\text { ad u lt st udy, } \\
\text { national datasets, } \\
\text { internal, and } \\
\text { external challenges } \\
\text { in finding and } \\
\text { maintaining jobs. } \\
\text { 2. There have been } \\
\text { linked as factors } \\
\text { that play a key role } \\
\text { in predicting work } \\
\text { such as social } \\
\text { d i s o m for t, } \\
\text { c o m o r b i d, } \\
\text { education level, } \\
\text { family support, } \\
\text { employer attitude, } \\
\text { access to services, } \\
\text { and de fect } \\
\text { incentives. }\end{array}$ & $\begin{array}{l}\text { 1. Future investigations into } \\
\text { the work results for all } \\
\text { individuals across the } \\
\text { spectrum. } \\
\text { 2. Current research does not } \\
\text { represent. But, only huge } \\
\text { groups of people are still } \\
\text { out of service systems. } \\
\text { 3. Need for a community- } \\
\text { based study based on the } \\
\text { work results for people with } \\
\text { ASD. }\end{array}$ \\
\hline
\end{tabular}




\begin{tabular}{|c|c|c|c|}
\hline $\begin{array}{l}\text { Employment } \\
\text { and vocational } \\
\text { skills among } \\
\text { individuals } \\
\text { with autism } \\
\text { spectrum } \\
\text { disorder: } \\
\text { Predictors, } \\
\text { impact, and } \\
\text { interventions } \\
\text { Walsh et al. } \\
\text { (2014) }\end{array}$ & $\begin{array}{l}\text { Aim to investigate } \\
\text { exist on predictors, } \\
\text { the impact of job or } \\
\text { v o c a t i o n a } 1 \\
\text { placement among } \\
\text { individuals ASD. }\end{array}$ & $\begin{array}{l}\text { 1. Has positive } \\
\text { recruitment impact } \\
\text { such as quality of } \\
\text { life, cognitive } \\
\text { function, and well- } \\
\text { being of people } \\
\text { with ASD } \\
\text { 2. P e s o n a a d d } \\
\text { external factors are } \\
\text { fou d a s a } \\
\text { c o m p } 1 \text { e x } \\
\text { interaction for } \\
\text { predictors of } \\
\text { employment. } \\
\text { 3. Interventions study } \\
\text { report progress in } \\
\text { targeted job skills, } \\
\text { though some skills } \\
\text { have been taught } \\
\text { throughout the } \\
\text { study. }\end{array}$ & $\begin{array}{l}\text { 1. Need further research in } \\
\text { employment and vocational } \\
\text { skills for individuals with } \\
\text { ASD and the availability of } \\
\text { less confirmation based } \\
\text { interventions. } \\
\text { 2. R e a c tion to tim e ly } \\
\text { interventions varies and } \\
\text { there is small data about } \\
\text { interventions affect need for } \\
\text { support as teenagers. }\end{array}$ \\
\hline $\begin{array}{l}\text { Postsecondary } \\
\text { education } \\
\text { employment } \\
\text { a n d } \\
\text { independent } \\
\text { l i v i n } \\
\text { outcomes of } \\
\text { persons with } \\
\text { autism and } \\
\text { intellectual } \\
\text { disability } \\
\text { Ross et al. } \\
(2013)\end{array}$ & $\begin{array}{l}\text { To report job and } \\
\text { direct decision of } \\
125 \text { graduates from } \\
\text { the Taft College } \\
\text { Transition program } \\
\text { to the Independent } \\
\text { Living Program. }\end{array}$ & $\begin{array}{l}\text { 1. T I L program } \\
\text { graduates have } \\
\text { free work and live } \\
\text { results beyond the } \\
\text { observed rates in } \\
\text { th e g e e r a } 1 \\
\text { population of } \\
\text { in t e lle c t u a } 1 \\
\text { dis ability and } \\
\text { development. } \\
\text { 2. The program may } \\
\text { be high motivation } \\
\text { as well as willing } \\
\text { than their peer. }\end{array}$ & $\begin{array}{l}\text { More studies involving } \\
\text { matching unit and well-made } \\
\text { treatments and controlled study. }\end{array}$ \\
\hline $\begin{array}{l}\text { A systematic } \\
\text { review of } \\
\text { vocational } \\
\text { interventions } \\
\text { for young } \\
\text { adults with } \\
\text { a u i s m } \\
\text { spectru m } \\
\text { disorders } \\
\text { Taylor et al. } \\
\text { (2012) }\end{array}$ & $\begin{array}{l}\text { Systematic reviews } \\
\text { of vocational } \\
\text { intervention for } \\
\text { A S D's pe op } 1 \text { e } \\
\text { between ages of } 13 \\
\text { and } 30 \text { years }\end{array}$ & $\begin{array}{l}\text { 1. A } 11 \text { are poor } \\
\text { quality and focus } \\
\text { on current job } \\
\text { support as a job / } \\
\text { v o c a t i o n a } 1 \\
\text { intervention. } \\
\text { 2. There are three } \\
\text { report studies that } \\
\text { interventions } \\
\text { i n c r e a s e } \\
\text { employment rates } \\
\text { for young ASD's } \\
\text { adult. }\end{array}$ & $\begin{array}{l}\text { Small evidence for specific } \\
\text { vocational approach for } \\
\text { individual transitions into adult. }\end{array}$ \\
\hline
\end{tabular}




\begin{tabular}{|c|c|c|c|}
\hline $\begin{array}{l}\text { Maintaining } \\
\text { vocational } \\
\text { skills of } \\
\text { individuals } \\
\text { with autism } \\
\text { a n d } \\
\text { developmental } \\
\text { disabilities } \\
\text { through video } \\
\text { modeling } \\
\text { Van Laarhoven } \\
\text { et al. (2012) }\end{array}$ & $\begin{array}{l}\text { To study the } \\
\text { effectiveness of } \\
\text { using vide o } \\
\text { modeling to } \\
\text { maintain vocational } \\
\text { skills of six } \\
\text { secondary school } \\
\text { students with ASD } \\
\text { and / or D D } \\
\text { throughout the } \\
\text { winter. }\end{array}$ & $\begin{array}{l}\text { 1. P a r i c i a nts } \\
\text { surveyed the video } \\
\text { and the results } \\
\text { s howed many } \\
\text { students increased } \\
\text { their independence } \\
\text { with both tasks } \\
\text { follow by video } \\
\text { m o d } 1 \mathrm{i} \mathrm{g} \\
\text { procedure. } \\
\text { The discovery has } \\
\text { been surprising but } \\
\text { consistent across } \\
\text { the student. }\end{array}$ & $\begin{array}{l}\text { 1. The findings from this } \\
\text { survey are surprising, but } \\
\text { provide relevant and } \\
\text { practical strategies for } \\
\text { various stakeholders who } \\
\text { are interested in not only } \\
\text { increasing the freedom of } \\
\text { s t u d e n s i } \mathrm{n} \text { j o b } \\
\text { arrangements, but also to } \\
\text { promote the maintenance } \\
\text { and impersonation of skills. } \\
\text { 2. Video overviews of } \\
\text { vocational settings may be } \\
\text { an efficient way of } \\
\text { improving, maintaining, } \\
\text { and practicing. }\end{array}$ \\
\hline
\end{tabular}

Based on the literature review, most researchers focus on generic skills such as social skills, independent living skills, and cognitive skills. Many are aware that the autism of autism individuals has problems with social skills, but if they are trained with proper and appropriate teaching techniques, individuals with autism can socialize in turn can communicate by themselves. According to the Malaysian Disability Action Plan, a strategic thrust 5 where to strengthen social services to these groups so they are more socializing with a lot of people (Department of Immigration and Border Protection, 2016). Besides, with the role of social work for people with disabilities and the quality of work where most of these works cover early intervention ideology so they can slip into their new social role evenly (Syriopoulou et al., 2016).

Besides that, the independent living skills of these individuals with autism are very important.

This is because most individuals who live depend on ASD where less than one per third have permanent jobs and most of them lives with their parents (Taylor \& McPheeters 2012; Taylor \& Seltzer, 2012). There are several indicators that measure the various aspects of free life for example lives in one's own house and pay the rent (Ross et al., 2013). At workplace, these people need to take care of themselves as an example, when they can rest, go to the toilet and do a work given by the employer because the employer does not always have to keep an eye on this group during working hours. In daily life, this skill is also very important in order for these groups to be less dependent and hoping for others to carry out their daily tasks.

ASD's people are believed to have certain cognitive toughness and flaw such as the difficulty in respecting the thoughts and feelings of others, the problem of regulating and controlling their behavior, and the ability to view details. In the last study, there were only a few studies that cognized the cognitive skills of individuals with autism but previous studies did not relate more in detail about the importance of cognitive skills among autism towards work. This skill are also very important to help these autism individuals at workplace such as to digest reading material where to make sure individual with autism can read and understanding text, thinking about things that related to work and can analyzing it. Besides that, to analyze problem and evaluate option where help them to decide which of several problems need to solve first. Finally, cognitive skills is important to make individual with autism can observe phenomena which mean being able to notice something and then pay attention about task that given in workplace.

\section{CONCLUSION}

This literature review presents information on research on the appropriate generic skills for adults autism can work. Overall, the findings of this literature studies show that many past studies relate and emphasize the importance of social skills among individuals with this autism when they work rather than skills such as independent living skills and there is little information about cognitive skills. Therefore, it may be noted that many early researchers emphasized social skills among autism 
individuals who wanted to work.

There are many limitations of this study as not many of the earlier studies tell or state more about generic skills among these autism individuals that are appropriate to a job. In addition, researchers need to conduct a deeper study by increasing the number of previous studies. Furthermore, the study to know the generic skills among autism individuals is very important as it can be a reference to other researchers and can improve the results of the study conducted later.

\section{ACKNOWLEDGEMENTS}

Authors would like to thank Ministry of Higher Education Malaysia for the Fundamental Research Grant Scheme (FRGS) of this project with Vote number 4F922.

\section{REFERENCES}

Chen, J. L., Leader, G., Sung, C., \& Leahy, M. (2015). Trends in employment for individuals with autism spectrum disorder: A review of the research literature. Review Journal of Autism and Developmental Disorders, 2(2), 115-127.

Department of Immigration and Border Protection. (2016). Disability Action Plan 2016-2022. Australian Government, Department of Home Affairs.

Hendricks, D. R. (2011). Review and Recommendations, 23284, 77-88.

Hendricks, D. (2010). Employment and adults with autism spectrum disorders: Challenges and strategies for success. Journal of Vocational Rehabilitation, 32(2), 125-134.

IOWA Department of Education. (2010). Parent factsheets: Talking to parents about autism. IOWA Department of Education.

Lancioni, G. E., \& O'Reilly, M. F. (2001). Self-management of instruction cues for occupation: Review of studies with people with severe and profound developmental disabilities. Research in Developmental Disabilities, 22(1), 41-65.

Ross, J., Marcell, J., Williams, P., \& Carlson, D. (2013). Postsecondary education employment and independent living outcomes of persons with autism and intellectual disability. Journal of Postsecondary Education and Disability, 26(4), 337-351.

Seaman, R. L., \& Cannella-Malone, H. I. (2016). Vocational skills interventions for adults with autism spectrum disorder: A review of the literature. Journal of Developmental and Physical Disabilities, 28(3), 479-494.

Syriopoulou Delli, C. K., Alexiou, I. P., \& Karampilia, D. (2016). Review on vocational training and employment of individuals with autism spectrum disorder. Journal of Educational and Developmental Psychology, 6(2), 84-96.

Taylor, J. L., McPheeters, M. L., Sathe, N. A., Dove, D., Veenstra-VanderWeele, J., \& Warren, Z. (2012). A systematic review of vocational interventions for young adults with autism spectrum disorders. Pediatrics, 130(3), 531-538.

Taylor, J. L., \& Seltzer, M. M. (2012). Employment and post-secondary educational activities for young adults with autism spectrum disorder during the transition to adulthood. Journal of Autism and Developmental Disorders, 41(5), 566-574.

Van Laarhoven, T., Winiarski, L., Blood, E., \& Chan, J. M. (2012). Maintaining vocational skills of individuals with autism and developmental disabilities through video modeling. Education and Training in Autism and Developmental Disabilities, 47(4), 447-461.

Walsh, L., Lydon, S., \& Healy, O. (2014). Employment and vocational skills among individuals with autism spectrum disorder: Predictors, impact, and interventions. Review Journal of Autism and Developmental Disorders, 1(4), 266-275. 